\title{
Modified Limberg Flap for Pilonidal Sinus
}

\author{
Thapa $\mathrm{PB}^{1}$, Maharjan $\mathrm{DK}^{2}$, Ghimire $\mathrm{R}^{2}$, Shrestha $\mathrm{SK}^{1}$
}

${ }^{1}$ Associate professor, ${ }^{2}$ Lecturer, Department of Surgery, Kathmandu Medical College Teaching Hospital

\author{
Address for correspondence \\ Dr. Prabin Bikram Thapa \\ Associate Professor \\ Department of Surgery, \\ Kathmandu Medical College Teaching Hospital \\ Sinamangal \\ E-mail: prabinbt@gmail.com
}

\begin{abstract}
Background: Pilonidal sinus disease is a common condition usually seen in young adults. Although several methods of treatment have been described, but all have been associated with high recurrence rates. This study was carried out to evaluate the advantages and results of rhomboid excision and Limberg flap reconstruction in the management of pilonidal sinus disease.

Objective: To evaluate the advantages and results of rhomboid excision and Limberg flap reconstruction in the management of pilonidal sinus disease

Material and Methods: This was prospective descriptive study conducted in Unit III, Department of Surgery, Kathmandu Medical College Teaching Hospital from August 2013 to August 2015. First 50 patients with diagnosis of pilonidal sinus were included .Exclusion criteria was patients with pilonidal abscess.

Results: Total 50 patient were included in 2 years time. Mean age was $23.48 \pm 3.9$ years with all male patients only. Median duration of surgery was $32 \pm 4.4$ minutes. Median time for normal activities was $21 \pm 3.9$ days and median follow up time was $18 \pm 8.5$ months. No recurrence was noted till then. Post surgery, patient applied hair removal cream: $44 \%$, hair shaving: $34 \%$ and laser therapy for hair follicles: $22 \%$.

Conclusion: Modified Limberg flap is better option for pilonidal sinus with least recurrence. However, post surgical counseling for hair removal is very important in order to prevent recurrence and should be multidisciplinary approach along with dermatologist colleagues.

Conflict of Interest: No

Key words: pilonidal sinus, modified limberg flap, hair removal
\end{abstract}

\section{Introduction}

P ilonidal disease is chronic inflammation of the hair follicles present at natal cleft of the sacrococcygeal area. It is an acquired disease resulting from invagination of broken hair into the skin, and subsequently inciting an inflammatory reaction. ${ }^{1-3}$ It was termed 'jeep driver's bottom disease' during World War II because many drivers were found to have the condition ${ }^{4}$.

Many modifications have been introduced for treatment methods of pilonidal sinus with varied recurrence rate (4 to $47 \%$ ) including wide local excision with primary suturing or healing by secondary intention to Bascom's technique, Karydakis surgery and modified Limberg Flap. ${ }^{5-10}$

Hence our objective is to evaluate the results of modified Limberg flap reconstruction in the management of pilonidal sinus disease.

\section{Material and Methods}

Study type, duration and location: This prospective cross sectional descriptive study was conducted from August 2013 to August 2015 in Unit III, Department of Surgery, Kathmandu Medical College Teaching Hospital, Sinamangal, Nepal. Ethical clearance for the study was obtained from the Institute Ethical Committee and all 
provisions of the Declaration of Helsinki were followed in this study.

\section{Data collection}

\section{Inclusion criteria}

All patients with diagnosis of pilonidal sinus were included in this study.

Exclusion criteria: Pilonidal abscess

\section{Modified Limberg flap procedure:}

Patient prepared in prone position with buttocks separated with tape. Superior and inferior points were placed $1.25 \mathrm{~cm}$ away from midline( Figure 1 ) and rhomboid tissue excised till the level of Gluteus muscle fascia. Then lateral subcutaneous flap was constructed based upon superior gluteal artery subcutaneous branch. We always tried to preserve subcutaneous branch of superior gluteal artery.

Negative suction drain $10 \mathrm{~F}$ was placed and subcutaneous fat sutured with absorbable polygalctin suture and skin was closed with mattress suture with non absorbable prolene suture.(Figure 2)

Patient was kept in left or right lateral position in post op ward and discharged on $2^{\text {nd }}$ day with drain. Drain was removed on $5^{\text {th }}$ post operative day and sutures were removed on $14^{\text {th }}$ post operative day.

Mean age, wound infection rate, were calculated. Patient was followed on $7^{\text {th }}, 14^{\text {th }}$ and $30^{\text {th }}$ post operative day.

Post operative patient were well explained about importance of hair removal either by hair epilation, shaving or permanent laser therapy for hair removal. They were taken care by combined dermatologist colleagues and us during follow ups for further management by hair removal procedures. All patients were followed up on $3^{\text {rd }}$ month, $6^{\text {th }}$ month, 1 year and 2 years of post operative period.

\section{Data Analysis}

Descriptive statistics of mean, standard deviation, percentage were obtained from the data. Statistical analysis was by SPSS statistical package version 10.1 .

\section{Results}

Total 50 patients were included in 2 years period. All were male patients:

\begin{tabular}{|l|l|}
\hline \multicolumn{2}{|l|}{ Demographic characteristics } \\
\hline Mean age group (years): & $23.48 \pm 3.971$ \\
\hline $\begin{array}{l}\text { Median duration of } \\
\text { surgery (minutes) }\end{array}$ & $32 \pm 4.4$ \\
\hline $\begin{array}{l}\text { Median time for normal } \\
\text { activities (days) }\end{array}$ & $21 \pm 3.9$ \\
\hline $\begin{array}{l}\text { Median Follow Up } \\
\text { (months) }\end{array}$ & $18 \pm 8.5$ \\
\hline $\begin{array}{l}\text { Post surgery therapy for } \\
\text { hair follicles: }\end{array}$ & $\begin{array}{l}\text { Hair removal cream: } 44 \% \\
\text { Lair Shaving : 34\% }\end{array}$ \\
\hline
\end{tabular}

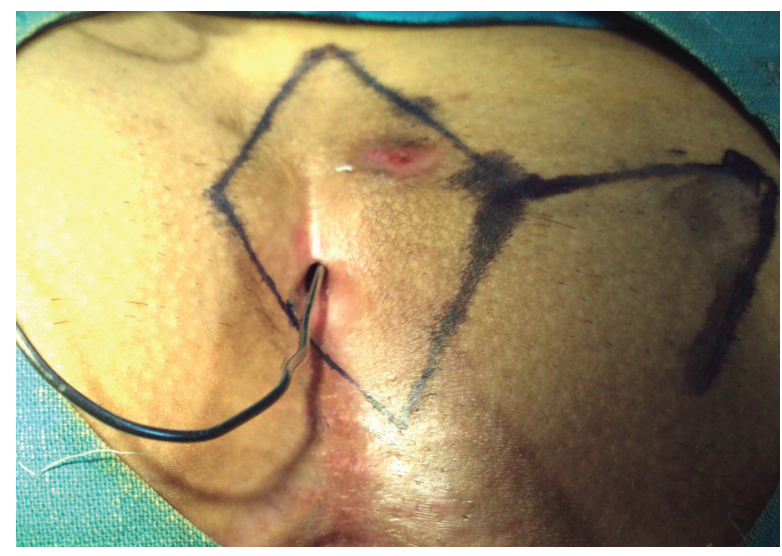

Figure 1: Marking of Rhomboid flap with lateralization from midline.

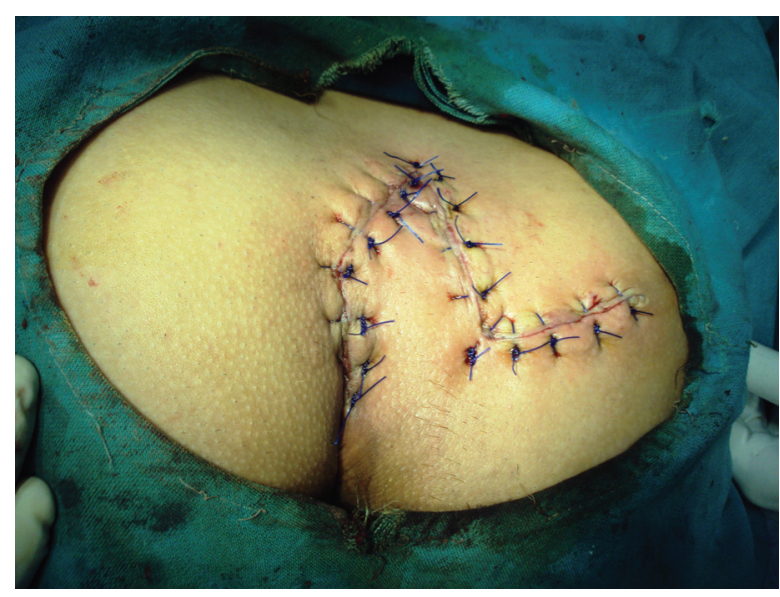

Figure 2: Wound after flap closure

\section{Discussion}

Various surgical procedure have been recommended for treatment of sacrococcygeal pilonidal sinus such as primary excision with lay open or primary closure; cleft closure procedure like Bascom's or Karydakis; different types of plasty like Z plasty, W plasty, V-Y plasty, and various flap techniques like Limberg, Defourmental flaps ${ }^{11-15}$. Despite different procedure, 
no optimal treatment approach with nil recurrence has been achieved.

The largest study done by Al-Salamah et $\mathrm{al}^{16}(\mathrm{n}=380$, with excision and primary closure (188 patients) and excision with lay open (192 patients) with follow up period for 3 years period have shown, no difference in the wound infection rate $(4.2 \%$ in primary closure vs $3.12 \%$ of open group). There was no significant difference in the recurrence rate of both the groups (3.7 vs. 3\%). The mean healing time and time off work in primary closure group was significantly shorter than the patients in open group. They recommended excision and primary closure, as it had the advantage of early wound healing, rapid return to work and comparable recurrence rate with excision and open wound.

However, metaanalysis done by McCallum et al ${ }^{17}$ (5 RCTs with $\mathrm{N}=559$ ) showed that excision compared to excision and primary closure have found a significant reduction in the recurrence rate in the excision-alone group (RR $0.38,95 \% \mathrm{Cl} 0.23$ to 0.63 ) though there was no difference between these techniques (RR 1.20, 95\% $\mathrm{Cl} 0.55$ to 2.63 ) in terms of postoperative infection.

Then studies where comparison between excision with primary closure and Limberg flaps have shown that Limberg flap have better results in terms of recurrence rate. While Holmebakk and Nesbakken ${ }^{18}$ reported a recurrence rate of approximately $20 \%$ after excision and primary closure .On the other hand, Ertan et al. ${ }^{19}$ determined a recurrence rate of $2 \%$ in the Limberg flap method and $12 \%$ in the primary closure method, and stated that the Limberg method resulted in a better outcome with respect to recurrence, complications, time required for wound healing, time required to return to work, and general health conditions.

\section{References}

1. Chintapatla S, Safarani N, Kumar S. Sacrococcygeal pilonidal sinus: Historical review, pathological insight and surgical options. Tech coloproctol 2003; 7: 3-8. https:// doi.org/10.1007/s101510300001

2. Sondeno K, Andersen E, Nesvik I, Spreide JA. Patient characteristics and symptoms in chronic pilonidal sinus disease. Int J Colorectal dis 1995; 10: 39-42. https://doi.org/10.1007/ BF00337585
Similarly, study by Ahmet et al ${ }^{20}$ have shown recurrence rate was $7.1 \%$ in classical Limberg flap than $9.2 \%$ in excision with primary closure ( $p$ value: 1.00 ).

High recurrence rate after treatment have been attributed to scar line at midline where movement is constant. Hence modification of classical Limberg flap was done into lateralization of midline incision which has demonstrated low recurrence rate ${ }^{21,22}$. In retrospective study done by Akin $\mathrm{M}$ et al ${ }^{23}$ have shown that the recurrence rate was statistically higher in the classical group than in the modified Limberg flap group $(P=0.036)$.

Our study showed lesser wound complication with modified Limberg flap .One patient had seroma after removal of drain on $5^{\text {th }}$ day and three patients had lower wound gapping due to poor hygiene of lower edge. No case of flap necrosis was noticed in our study. However 30 patients complain of numbness over flap after 2 years of follow up.

We emphasis that post surgical patient counseling regarding hair removal is more important for prevention of recurrence and hence we recommend that it should be standard practice to refer to dermatologist colleagues as a part of multidisciplinary approach for post operative management of pilonidal sinus.

\section{Conclusion}

Modified Limberg flap is better option for pilonidal sinus with least recurrence. However, post surgical counseling for hair removal is very important in order to prevent recurrence and should be multidisciplinary approach along with dermatologist colleagues.

3. Mentes O, Bagci M, Bilgin T, Coskun I, Ozgul $\mathrm{O}$, Ozdemir M. Management of pilonidal sinus disease with oblique excision and primary closure results of 493 patients. Dis Colon Rectum 2006; 49: 104-108. https://doi. org/10.1007/s10350-005-0226-2

4. Solla JA, Rothenberger DA. Chronic pilonidal disease: An assessment of 150 cases. Dis Col Rec 1990; 33: 758-61. https://doi.org/10.1007/ BF02052321

5. Jones DJ. $A B C$ of colorectal diseases: Pilonidal sinus. BMJ 1992; 305: 410-2. https://doi. org/10.1136/bmj.305.6850.410 
6. Berry DP. Pilonidal sinus disease. J Wound Care 1992; 1: 29-32. https://doi.org/10.12968/ jowc.1992.1.3.29

7. Jensen SL, Harling $\mathrm{H}$. Prognosis after simple excision and drainage for a first episode acute pilonidal abscess. Br. J. Surg 1988; 75: 60-1. https://doi.org/10.1002/bjs.1800750122

8. Fuzun $M$, Bakir $H$, Soylu M, Tansug $T$, Kaymak E, Harmancioglu O. Which technique for treatment of pilonidal sinus: Open or closed? Dis. Colon Rectum 1994; 37: 1148-50. https:// doi.org/10.1007/BF02049819

9. Lee PJ, Raniga S, Biyani DK, Watson AJ, Faragher IG, Frizelle FA. Sacrococcygeal pilonidal disease. Colorectal Dis 2008; 10: 639-50. https://doi. org/10.1111/j.1463-1318.2008.01509.x

10. Al-Hassan HK, Francis IM, Neglen P. Primary closure or secondary granulation after excision of pilonidal sinus? Acta Chir Scand 1990; 156: 695-9.

11. Katsoulis IE, Hibberts F, Carapeti EA. Outcome of treatment of primary and recurrent pilonidal sinuses with the Limberg flap. Surgeon 2006; 4: 7-10. https://doi.org/10.1016/S1479666X(06)80014-4

12. Karydakis GE. Easy and successful treatment of pilonidal sinus after explanation of its causative process. Aust. N.Z. J. Surg 1992; 62: 385-9. https://doi.org/10.1111/j.1445-2197.1992. tb07208.x

13. Ates M, Dirican A, Sarac M, Aslan A, Colak C. Short and long-term results of the Karydakis flap versus the Limberg flap for treating pilonidal sinus disease: a prospective randomized study. The American Journal of Surgery 2011; 202(5): 568-73. https://doi.org/10.1016/j. amjsurg.2010.10.021

14. Bascom JU. Pilonidal disease: Long-term results of follicle removal. Dis. Colon Rectum 1983; 26: 800-7. https://doi.org/10.1007/BF02554755

15. Lee HC, Ho YH, Seow CF, Eu KW, Nyam D. Pilonidal disease in Singapore: clinical features and management. Australian and New Zealand
Journal of Surgery. 2000; 70(3): 196-8. https:// doi.org/10.1046/j.1440-1622.2000.01785.x

16. Al-Salamah SM, Hussain MI, Mirza SM. Excision with or without primary closure for pilonidal sinus disease. JPMA. 2007; 57(8): 388-91.

17. McCallum I, King PM, Bruce J. Healing by primary versus secondary intention after surgical treatment for pilonidal sinus. Cochrane Database Syst Rev 2007. https://doi. org/10.1002/14651858.CD006213.pub2

18. Hølmebakk T, Nesbakken A. Surgery for pilonidal disease. Scandinavian journal of surgery. 2005; 94(1):43-6. https://doi. org/10.1177/145749690509400111

19. Ertan T, Koc M, Gocmen E, Aslar AK, Keskek M, Kilic M. Does technique alter quality of life after pilonidal sinus surgery?. The American journal of surgery 2005; 190(3): 388-92. https://doi. org/10.1016/j.amjsurg.2004.08.068

20. Karaca AS, Ali R, Çapar M, Karaca S. Comparison of Limberg flap and excision and primary closure of pilonidal sinus disease, in terms of quality of life and complications. Journal of the Korean Surgical Society 2013; 85 (5): 236-9. https://doi.org/10.4174/jkss.2013.85.5.236

21. Yildiz T, Ilce Z, Kücük A.Modified Limberg flap technique in the treatment of pilonidal sinus disease in teenagers. J Pediatr Surg 2014; 49(11): 1610-3. https://doi.org/10.1016/j. jpedsurg.2014.06.011

22. Cihan A, Ucan BH, Comert M, Cesur A, Cakmak GK,Tascilar O. Superiority of asymmetric modified Limberg flap for surgical treatment of pilonidal disease. Dis Colon Rectum 2005; 49: 244-9. https://doi.org/10.1007/s10350-0050253-z

23. Akin $M$, Leventoglu $S$, Mentes BB, Bostanci H, Gokbayir H, Kilic K, Ozdemir E, Ferahkose Z.Comparison of the classic Limberg flap and modified Limberg flap in the treatment of pilonidal sinus disease: a retrospective analysis of 416 patients. Surg Today. 2010; 40(8): 75762. https://doi.org/10.1007/s00595-008-40987. 